\title{
Indigenous Lands at Risk: Identifying Global Challenges and Opportunities in the Face of Industrial Development
}

\section{Christina M. Kennedy ( $\square$ ckennedy@tnc.org )}

The Nature Conservancy https://orcid.org/0000-0001-8902-8728

\section{Brandie Fariss}

The Nature Conservancy

James R. Oakleaf

The Nature Conservancy

\section{Stephen T. Garnett}

Charles Darwin University

\section{Álvaro Fernández-Llamazares}

University of Helsinki

Julia E. Fa

Manchester Metropolitan University

\section{Sharon Baruch-Mordo}

TRAFFIC International

Joseph Kiesecker

The Nature Conservancy

\section{Research Article}

Keywords: Community-based conservation, Indigenous land rights, Indigenous stewardship, biocultural conservation, conservation planning, risk assessment, industrial development expansion, free prior and informed consent

Posted Date: January 5th, 2022

DOI: https://doi.org/10.21203/rs.3.rs-1202963/v2

License: (c) (i) This work is licensed under a Creative Commons Attribution 4.0 International License. Read Full License 


\section{Abstract}

Indigenous Peoples' (IP) stewardship has helped conserve biodiversity and maintain healthy ecosystems worldwide. Among many challenges to this role are mounting pressures from industrial development. By assessing the current ecological condition of Indigenous lands with their potential for future industrial development, we show that the ecological integrity of $22 \%$ (8.6 million $\mathrm{km}^{2}$ ) of Indigenous lands is highly threatened across five continents and 37 countries. We further find that the risk to Indigenous lands is greatest across West and Central Africa because of their high ecological threat and greater obstacles for Indigenous Peoples to realize self-determined and culturally-responsive development outcomes. Using a novel national-level framework that examines the security of IP' rights and authority over their lands, their capacity to engage in decision-making, and support for facilitating sustainable development, we highlight potential challenges and opportunities for strategic investments and interventions to help IP safeguard their futures and rights, as well as the ecological integrity of their lands.

\section{Introduction}

Indigenous Peoples (IP) comprise less than $5 \%$ of the global population, yet they formally or customarily govern at least a quarter of the world's land and freshwater resources ${ }^{1}$ (see Supplemental Glossary of Key Terms for definitions of italicized words). Their stewardship of these landscapes, together with their interwoven practices, worldviews and knowledge systems, has helped to conserve global biodiversity ${ }^{2}$, mitigate climate change ${ }^{3}$, and provide essential benefits to the whole of society ${ }^{2,4}$. However, many Indigenous lands are experiencing mounting pressures from commercial agriculture, mining, energy, and infrastructure projects ${ }^{5-7}$. Numerous case studies illustrate the pervasive struggle of IP against industrial development and large-scale extractive projects often misaligned with their cultural, spiritual, and environmental values; ${ }^{6,8}$ and with adverse impacts on IP' livelihoods and wellbeing ${ }^{4,9}$. Even where IP might potentially benefit, they are commonly disempowered from influencing land use decisions that avoid negative impacts. This perpetuates a history of dispossession ${ }^{10}$, marginalization and denial of IP' self-determination and continued stewardship when confronted by outside interests ${ }^{5,6}$.

Yet, the global extent and patterns of threats to Indigenous lands from multiple types of industrial development remain largely unquantified. Equally unknown is how national socio-economic and political contexts might influence the risk of such development proceeding without IP' consent and in ways that undermine their values and visions.

We build upon previous work on the global extent of Indigenous lands ${ }^{1}$, and evaluate their potential for industrial development expansion. We measure threat to the ecological integrity of Indigenous lands ${ }^{11}$ by considering their suitability for energy, mining, agricultural, and urban expansion ${ }^{12}$. Though we recognize that IP might value their lands and weigh the severity of the threats they confront differently (see Supplemental Positionality and Framing Statement for further details), we define highly threatened Indigenous lands as those with high ecological integrity and high exposure to future development pressures (Fig. 1), which could result in negative impacts on both people and nature ${ }^{4,9}$. We define risk in 
relation to industrial development occurring where socio-economic and political contexts are unfavorable to IP' self-determination and continued stewardship. For this purpose, we generate a novel national-level framework and derive an accompanying spatially-explicit composite index, which we call the AuthorityCapacity-Support (ACS) Index. We use the ACS Index to provide a high-level overview of the challenges to Indigenous stewardship posed by development threats occurring in unfavorable national contexts, as well as to suggest where and what types of strategic investments might be taken by conservation actors committed to supporting Indigenous stewardship.

National indicators have been used to assess the vulnerability of local communities to threats like natural hazards or climate-related events, and their capacity to respond effectively ${ }^{13,14}$, to determine conservation priorities ${ }^{15}$, and to define enabling conditions for successful community-based conservation ${ }^{16}$. Here we use national indicators to assess risk to Indigenous lands by developing a framework to characterize the strength and security of IP' rights and authority over their lands, their capacity to meaningfully engage and be represented in the decision-making processes impacting them, and the capital and support available for facilitating conservation and sustainable development (Fig. 2). Our ACS framework was informed by other environmental risk and resilience indicators ${ }^{13,14}$, as well as existing community-based conservation and sustainable livelihoods frameworks ${ }^{2,17-19}$ that identify important enabling conditions for collective action, effective governance, and successful communitybased natural resource management, including secure rights to territories and resources 20,21 , strong institutions and leadership ${ }^{22}$, effective forums for multi-stakeholder engagement ${ }^{23}$, place-based economic opportunities, and equitable financing ${ }^{24}$. We created the ACS index based on national-level data on IP' legal security over their land and resources, political stability, control of corruption, environmental democracy, human development, and investments in sustainable development goals.

We illustrate how the ACS index can be used to contextualize threats to the ecological integrity of Indigenous lands, evaluate their relative risk in relation to the context in which they occur, and help guide national-level geographic and strategic priorities. Our results point to areas of the world where Indigenous lands of high ecological integrity are at greatest risk. We also identify opportunities for conservation practitioners, governments, funders, and multi-lateral organizations to bolster equitable governance ${ }^{25}$ and the continued stewardship of Indigenous lands by Indigenous Peoples through a combination of local and supralocal strategies and actions (Table 2). More broadly, our results highlight the urgent need to foreground IP rights, leadership, and agency in the post-20202 Global Biodiversity Framework ${ }^{26}$.

\section{Results}

Development threats to the ecological integrity of Indigenous lands. The vast majority of Indigenous lands ( 92\%, 35.4 million $\left.\mathrm{km}^{2}\right)$ are only marginally modified by human activities, remain in moderate to good ecological condition (Fig. 1a, Supplemental Results), and represent critical landscapes for biodiversity and carbon sequestration ${ }^{27}$. At the same time, our results show that they are under significant pressure from potential expansion of industrial development. Based on an overlay of land 
suitability maps of the potential for future expansion by renewable energy, oil and gas, mining, commercial agriculture, and urban sectors ${ }^{12}$, we show that nearly a quarter of all Indigenous lands have what we define as high industrial development pressure from one or more of these sectors (see methods on definitions) (Fig. 1b). When considering current ecological condition of these lands with high industrial development pressure, we determine over 22\% (8.6 million $\mathrm{km}^{2}$ ) to be highly threatened (Fig. $1 \mathrm{~d}$ ) and an additional $37 \%\left(14.1\right.$ million $\left.\mathrm{km}^{2}\right)$ to be moderately threatened. This total represents a significant portion of Indigenous lands across 5 continents and 37 different countries (Supplementary Data 1).

Renewable energy is the dominant driver of high development pressure on $42 \%$ of Indigenous lands (3.6 million $\left.\mathrm{km}^{2}\right)$, driven largely by solar $(81 \%)$, wind $(13 \%)$, hydro power $(1 \%)$ or these sectors combined $(5 \%)$. Pressure from renewables is widely distributed and dominates in Australia, and parts of China, central Africa, Argentina, United States and Pakistan (Fig. 1c). This finding is notable, as renewable energy development has obvious environmental benefits and might help Indigenous communities overcome barriers to energy justice. Yet, like conventional oil and gas development ${ }^{5}$, IP have had negative experiences with renewable projects, and voiced strong concerns over land grabbing, lack of local benefits, and associated environmental and socio-cultural impacts ${ }^{28}$.

Other drivers of high development pressure on Indigenous lands are oil and gas (18\%, 1.6 million $\left.\mathrm{km}^{2}\right)$, commercial agriculture for crops and biofuels $\left(14 \%, 1.2\right.$ million $\left.\mathrm{km}^{2}\right)$, or multiple sectors combined $(13 \%$, 1.1 million $\mathrm{km}^{2}$ ). Oil and gas are major drivers of future development pressure in six countries (Russia, Norway, Ecuador, Guatemala, Paraguay, and New Zealand) and commodity agriculture in 14 countries (Democratic Republic of Congo, India, Indonesia, Morocco, Myanmar, Ivory Coast, Malaysia, Viet Nam, Nepal, Guyana, Nicaragua, Belize, Sri Lanka, Burundi). Palm oil production, for example, has negatively impacted IP and local communities in Indonesia and Malaysia, with frequent issues over land conflicts and poor living conditions despite modest improvements in employment and income ${ }^{29}$.

Mining pressure for coal, metallic and non-metallic resources is the dominant driver on only $9 \%$ ( 0.8 million $\mathrm{km}^{2}$ ) of Indigenous lands, but it has significant negative impacts on Indigenous communities and their lands despite its relatively small footprint ${ }^{9,30}$. For example, gold mining in the Brazilian Amazon has exposed IP to increased rural violence, contamination by toxic pollutants, and exposure to contagious diseases ${ }^{30}$. Mining is a leading development pressure on Indigenous lands in 12 countries, including Peru, Greenland, Sweden, Laos, Finland, Philippines, Panama, Honduras, New Caledonia, El Salvador, Taiwan, and Costa Rica.

Lastly, urbanization is the dominant driver on $4 \%\left(0.3\right.$ million $\left.\mathrm{km}^{2}\right)$ of Indigenous lands globally, particularly in Gambia and Rwanda, though there are also significant areas in Nigeria, Pakistan, Burkina Faso, Senegal, Niger, Indonesia, Mali, China, DR Congo, India, Ethiopia, and Argentina. Though negative impacts are less direct, the pressures of urbanization can radically transform IP' cultures, and lead to inter-generational erosion of language, identity, traditional practices, and knowledge systems ${ }^{31,32}$. Top- 
down urbanization programs have also been criticized for more direct negative impacts, including dispossession, displacement, and landlessness ${ }^{33}$.

National context and development risk to Indigenous lands. Low Authority-Capacity-Support Index scores suggest national contexts that are less favorable to Indigenous stewardship because IP' rights and decision-making authority are insecure, the capacity for engagement and representation in decisionmaking processes is challenged, and support for conservation and sustainable development is inadequate. When evaluating socio-economic and political context alone, we find that 11 countries with Indigenous lands have very low ACS Index scores (ranging from 0.13-0.31 on 0-1 scale); all are in Africa and Central/Southeast Asia (Fig. 2, Supplementary Data 1).

When combining threatened Indigenous lands (Fig. 3a) with their ACS scores (Fig. 3b), we found high development risk for Indigenous lands in countries concentrated in Africa $(n=30,64 \%)$, followed by Central/South America $(n=10,21 \%)$, South/Southeast Asia $(n=4,9 \%)$ and the Middle East $(n=3,6 \%)$ (Fig. 3c). A focus on how context might influence development trajectories for countries with highly threatened Indigenous lands, shows that development risk rank increased by $\geq 10$ for eight African countries, suggesting greater challenges for IP in those contexts confronting development proposals (Fig. 4a-b; denoted in pink; Democratic Republic of the Congo, Niger, Chad, Republic of Congo, Mali, Côte d'Ivoire, Gambia, and Gabon). Other countries have negligible shifts but still represent challenges given their already high development threat potential (Fig. 4a-b; denoted in gray). These also occur in Africa, as well as three in Central/South America, and one in the Middle East. In contrast, 14 countries have national contexts that decrease their risk rank by $\geq 10$, potentially representing more favorable contexts for Indigenous stewardship (Fig. 4a-b; denoted in green). These include seven countries in South America, three in Europe, two in Africa, the United States, and Australia.

Challenges and opportunities to support Indigenous stewardship. An analysis of the sub-components of the ACS Index helps to disaggregate which aspects of national context contribute most to development risk (Table 1). Here we use the ACS Index to suggest geographies where strategies and conservation actions might be leveraged to support continued stewardship of Indigenous lands by IP, ranging from community-level intervention to national-level policy reform (Table 2).

Of the eight African countries identified as having highly threatened Indigenous lands and relatively less favorable contexts (see Fig. 4a), 75\% $(n=6)$ had significantly lower scores for authority over their lands and support for achieving Indigenous-led conservation and sustainable development $(>1$ mean absolute deviation or MAD from the global median). In addition, $50 \%(n=4)$ had significantly lower scores with regard to the capacity for engagement and representation in decision-making processes (Table 1). This general pattern was consistent across all countries with highly threatened Indigenous lands $(n=34)$ : with $50 \%$ having significantly lower authority scores, $26 \%$ having significantly lower support scores, and $21 \%$ having significantly lower capacity scores relative to the global median. 
Insecure rights and decision-making authority remain an issue for IP even in the 14 countries with high development threat and relatively more favorable contexts (see Fig. 4a) The authority scores for Argentina and Finland in particular, are significantly lower than most other countries (Table 1). In addition to a general weakness in authority, all South American and African countries have, at best, average capacity and/or support scores (< 1 MAD within the global median), suggesting there is room for improvement in the support offered to IP facing encroachment of industrial development on their lands.

\section{Discussion}

In line with previous assessments ${ }^{1}$, as much as $39 \%$ of the world's least modified and most ecologically intact lands are stewarded by IP (Supplemental Results). The current ecological condition of these lands reflects a long history of use shaped by Indigenous Knowledge systems, ethics, livelihoods, and traditional land use practices, often supportive of or compatible with biodiversity and the provision of ecosystem services ${ }^{2,4}$. Alarmingly, we also find that almost $60 \%$ of all Indigenous lands have the potential to be moderately to highly threatened by future industrial development. Increasing demands on Indigenous lands from the expansion of commodity-based and extractive activities are frequently accompanied by negative impacts, including injustices and violence against Indigenous communities ${ }^{8}$ and increased exposure to environmental pollutants and disease 9,30; endangering lives, and the collective continuation of IP' cultures, livelihoods, and ways of life ${ }^{6,32,34}$. We find that such development threats are particularly prevalent within Indigenous lands across 37 countries in Africa, Central and South America, Europe, North America, Oceania, and the Middle East. We also suggest that the general patterns revealed by intersecting threatened Indigenous lands with the national-level contexts captured by the Authority-Capacity-Support Index (Table 1) can point to where and what types of strategic investments are needed to create the enabling conditions for equitable and effective engagement of IP in the Free, Prior, and Informed Consent (FPIC) process ${ }^{35}$ and their continued stewardship of these critical landscapes.

Authority. Across all countries with highly threatened Indigenous lands, even those with relatively more favorable national contexts, we find that weaknesses in authority are most pervasive (Table 1). FPIC is critical to Indigenous-led conservation and sustainable development; and a full and effective FPIC process is often precluded when IP' rights are insecure and their authority to act as decision-makers over their lands, waters, and resources is not fully recognized. Where IP' rights and decision-making authority are insecure, we suggest community- and supra-community-focused actions that might strengthen them (Table 2). For example, community-focused actions might include clarifying customary de facto rights through participatory mapping and other means of demarcation, formalizing rights through registration and titling, or strengthening community capacity to enforce those rights. Such actions have been undertaken to support IP' sovereignty ${ }^{2}$ and strengthen their capacity to govern ${ }^{36,37}$, which has worked to counter the threat of land grabs associated with commodity-driven development, ranging from biofuel production ${ }^{38}$ to livestock rearing, mining, and large-scale agro-business ${ }^{39}$. In particular, participatory mapping tools ${ }^{40}$ and counter-mapping approaches ${ }^{41}$ are gaining momentum in 
efforts to strengthen IP' authority and deter corporate land grabbing, for example in regions like SubSaharan Africa ${ }^{42}$ and Central Kalimantan, Indonesia ${ }^{43}$. In the Peruvian Amazon, formalization of IP' customary rights to the forest through titling has reduced deforestation and disturbance associated with unsustainable commodity agriculture or lease for "timber mining" 44, 45. Meanwhile, actions focused beyond the community might include the promotion of institutional awareness and commitments to strengthening IP' rights, and the development of frameworks and guidance for practitioners on how best to strengthen tenure security $2,18,46$.

Capacity. Even when IP' authority is strong, the capacity for their engagement and representation in existing decision-making processes can be challenged by factors internal and external to the community. Though capacity-building at the community level is often needed, external challenges exist in many countries (Table 1), and variously scaled actions may be relevant in promoting the capacity for IP to engage and be better represented in decision-making processes (Table 2). For example, communityfocused actions might include creating or strengthening existing community institutions, and building their capacity to participate and navigate existing processes through training and technical support in negotiation, conflict resolution, and financial management. ${ }^{47}$ Such actions have allowed IP to hold governments and companies accountable for making more than a token effort to consult them ${ }^{28,48}$. These community-focused actions should also occur in tandem with actions taken beyond the community. For example, enforcement of existing frameworks that call for equity and inclusion (UNDRIP, Article 15), the development and adoption of corporate social responsibility standards and best practices in engagement 49,50 , and structural changes that remove barriers to participate and elevate Indigenous Knowledge and institutions into all stages of the development process ${ }^{51,52}$. Lastly, multi-stakeholder forums that facilitate networking and representation in the larger decision-making space are also crucial 23. Collectively, these interventions could better ensure that IP can inform development trajectories better aligned with their values and visions; and position themselves to benefit from development of their lands while avoiding pitfalls associated with their opposition to it. For example, a recent wind energy project in South Dakota gave controlling interest to a newly formed tribal coalition and supported them through capacity-building efforts focused on transfer of ownership and governance of the utility by its constituent Sioux members, allowing some direct, local benefits to be realized ${ }^{53}$.

Support. Our index also highlights geographies, particularly in Africa (Table 1), where capital and support are needed to ensure that IP facing incompatible development proposal(s) can be supported (Table 2). Community-focused actions might include the provision of technical capacity or training around community planning; as well as the development of decision-support tools that allow IP to assess the potential impacts of proposed development projects in consideration of socio-cultural values ${ }^{54}$. In addition, the same tools could be used by communities to explore alternative development scenarios and economic opportunities, like payment for ecosystem services (PES), which have the potential to offer IP an alternative to industrial development more aligned with cultural practices and values ${ }^{55}$, as has been negotiated with Aboriginal fire management programs across Northern Australia ${ }^{56}$. Strict enforcement and adherence to existing impact mitigation and land use planning frameworks and processes can also 
support IP. Multi-lateral development bank lending standards might be useful in this regard, including the World Bank's Environmental and Social Standard ESS7 ${ }^{57}$ and International Finance Corporation's Performance Standard $7^{58}$ on Indigenous Peoples. Additionally, Environmental and Social Impact Assessments can limit the impacts of development projects on affected landscapes and communities and support a path toward FPIC ${ }^{54}$. However, existing lending standards, impact assessments, and safeguards fail to deliver necessary protections and should be strengthened to ensure that development planning and mitigation efforts are inclusive of IP, and holistically account for socio-cultural considerations alongside environmental impacts ${ }^{6,59}$. Beyond these measures, partnerships between government, civil society and companies can help secure the financial investments required to support Indigenous-led conservation and sustainable development, as demonstrated by the recent pledge of $\$ 1.7$ billion for tropical forest protection via strategies focused on securing customary rights of IP 60 .

Caveats and limitations. Although we used the best available global datasets on Indigenous lands, development pressures, and national indicators, these datasets have limitations with respect to spatial accuracy and completeness. Our map of Indigenous land is based on the definition of Indigeneity adopted (see Methods), and is not fully resolved nor mapped with the same precision across nations ${ }^{1}$. This definitional caveat also applies to LandMark's indicator of IP' legal security (see Supplementary Table 6 for an analysis of their alignment). In addition, our analysis does not cover certain regions that may be subject to many of the same development pressures: such as small islands of Oceania, Madagascar, or in large parts of central Asia, where there are local communities that do not adhere to our working definition of IP, or large regions of Canada, where the only publicly available maps likely underrepresent Indigenous lands ${ }^{1}$. Therefore, future assessments should be updated as new information on Indigenous lands becomes publicly available, particularly that which is recently emerging from Indigenous-led mapping efforts (e.g., https://native-land.ca/) ${ }^{37}$.

To capture development pressure on Indigenous lands, we relied on maps that indicate highly suitable areas for the expansion of industrial development based on the presence of large reserves of unexploited resources, and the presence of infrastructure that can support their extraction and transportation. These sector suitability maps do not capture other aspects of feasibility, such as property type, regulatory quality, or the ease of doing business within a country. They also do not account for production demands due to uncertainties in predicting them, lack of data for doing so, and the ever-changing policies and incentives that affect demand. As such, our development pressure maps may not adequately capture frontier expansion made possible by investments in new infrastructure; and may over-estimate near-term expansion by specific sectors, such as renewable energy. At the same time, the areas of high development pressure we mapped do reflect general patterns of projected expansion when production demands are considered ${ }^{61}$. Thus, our development pressure mapping should be interpreted as the relative suitability of Indigenous lands for expansion by different industrial sectors, and not the exact location of development siting or the total land area that will be converted. 
Beyond the technical caveats associated with some of the inputs to our analysis, there are also epistemological ones. We measure threat to the ecological integrity of Indigenous lands specifically, given their urgency from a conservation and human rights perspective. We acknowledge that this measure of threat is situated and partial and may not adequately reflect how IP might value their lands or weigh the severity of the threats they confront (see Supplemental Positionality and Framing). However, we posit that encroachment by industrial development has the potential to impinge negatively on Indigenous lands, regardless of the diverse values and priorities that might be attributed to them ${ }^{5,8}$. Although our measure of threat is far from universal, we believe that it is an important first step in supporting Indigenous Peoples to realize self-determined and culturally-responsive development futures. Our effort should therefore be seen as an interim measure until new indicators evolve from transformative research settings led by or co-created with Indigenous communities. We believe that endeavors in this vein can support the identification of metrics that are attuned to both local cultural needs and global priorities, and contribute to our collective efforts to address the injustices brought about by colonial conservation approaches ${ }^{6}$.

While the ACS index was constructed of indicators with hypothesized importance to governance and stewardship (see Supplemental Material) ${ }^{2,17-24}$, we encourage a precautionary approach in its application for decision-making. Our ACS Index relied on national-level data to characterize the security of IP' rights and authority over their lands, their capacity to engage and be represented in the decisionmaking processes impacting them, and the support available for facilitating Indigenous-led conservation and sustainable development. While there is evidence that national-level indicators can mediate local realities and community-level outcomes ${ }^{16,62}$, we recognize that there are variations in local enabling conditions and governance arrangements, particularly in regions with complex historical contingencies, where highly variable state, provincial, or territorial policies exist, or rapid shifts in the political climate have occurred ${ }^{7}$. Due to data limitations, we also relied on national-level data that were not always specific to IP. Thus, our estimates of authority, capacity and support are best used as a relativized global characterization of context and considered best-case scenarios for IP within a particular country since they are frequently among the most marginalized ${ }^{63}$. We suggest that the ACS index, combined with our threat assessment, can be used as a coarse filter to screen and identify broad regions where strategic investments and interventions could help IP safeguard their futures and rights, as well as the ecological integrity of their lands. Future directions could take a case study approach and engage IP to ground-truth and refine indicators of authority, capacity, and support with community-specific knowledge and culturally-relevant data (e.g., title, presence and strength of community institutions, instances of corruption or elite capture among leadership, localized investments in sustainability initiatives or conservation programs).

Supporting Indigenous Stewardship. Despite the tremendous public good resulting from their stewardship, many Indigenous communities suffer from severe poverty and would welcome sustainable development ${ }^{63}$. Instead, they confront mounting pressures from extractive and commodity-driven development ${ }^{5-8}$, much of which has been exploitive and tacitly oppressive in nature, with little or no 
promise of local benefits ${ }^{5}$. Our assessment underscores that a significant proportion of the world's Indigenous lands face pressures from industrial development that IP consider unwelcome, and that regions across West and Central Africa are at particularly high risk due to their relatively less favorable socio-economic and political contexts. Business-as-usual approaches have clearly fallen short of equitably and effectively engaging IP in determining development futures on Indigenous lands 64,65 . Realizing the principle of FPIC is a human rights imperative, recognized under international law, enshrined in the United Nations Declaration on the Rights of Indigenous Peoples, the UN Universal Declaration of Human Rights, and the International Labour Organization's Convention No. 169 on Indigenous and Tribal

Peoples, as well as the Convention on Biological Diversity and domestic laws of many countries ${ }^{35}$. While world-wide calls to "defend the defenders" are on the rise ${ }^{66}$, much remains to be done to prevent continued attacks, intimidation, and threats against IP, stewarding these crucially important lands amidst ever-increasing industrial development pressures $5,6,12$. This study underscores that transformative action is urgently needed beyond the community to drive structural, institutional, and policy changes. In addition, community-level interventions are critical to strengthen IP' rights and decision-making authority over their lands, ensure their capacity to engage and be represented in decision-making processes impacting them, and bolster the level of support they require to realize conservation and sustainable development (Table 2). Collectively, such actions can encourage culturally responsive, self-determined development trajectories compatible with continued IP stewardship and help to uphold IP rights, leadership and agency in several ongoing global efforts to address biodiversity loss and climate change ${ }^{26}$.

\section{Methods}

To assess industrial development threat and risk on Indigenous lands, we used spatial datasets at 1-km resolution for the (1) geographical extent of Indigenous lands; (2) human modification of terrestrial lands used as proxy for ecological integrity; (3) land suitability maps for future development expansion by commodity-based and extractive economic sectors that provide development pressure indices; and (4) a novel national-level index, referred to as the Authority-Capacity-Support Index, which combines six national-level datasets to capture the social, economic and political contexts that can either promote or hinder continued stewardship of these lands by IP. All geospatial analyses were conducted in the Mollweide projection, an equal-area map projection, using ArcGIS 10.8.1 software (www.esri.com) with the Spatial Analyst extension. We applied bilinear resampling method for continuous raster data and nearest-neighbor method for discrete data (vector data were first projected and then converted to raster datasets). For national-level analyses, we used country boundaries sourced from the Global Administrative Areas (GADM) spatial database version 2.8 (https://gadm.org/).

Indigenous lands. We used the boundaries of Indigenous lands mapped by Garnett, Burgess ${ }^{1}$, who identified Indigenous lands across 87 countries or politically distinct areas. This dataset represents the most comprehensive assessment of terrestrial lands where IP have customary ownership, management, or governance arrangements in place, regardless of legal recognition. It is based on 127 publicly available 
sources, including cadastral records, participatory maps, and census data. We adopt their definition of IP as those who identify as having "descended from populations which inhabited a country before the time of conquest or colonization [and] who retain at least some or all of their own social, economic, cultural and political institutions" (see Key Terms in Supplemental Glossary) As discussed in Garnett, Burgess ${ }^{1}$, we note the practical and ethical challenges of defining IP and the implications for mapping their lands (see their SI for further details). As a result, the Indigenous lands map should not be used to identify specific territories or legal claims, nor should areas without delineation be interpreted as lacking IP' presence, claim or interest. We also acknowledge that voids in these maps do not necessarily imply an absence of IP, but rather areas for which their presence cannot be determined from publicly available geospatial resources.

Development Threat on Indigenous Lands. We calculated a development threat score for each Indigenous land cell as a function of its ecological condition or degree of naturalness from the Human Modification (HM) dataset, and its cumulative development pressure from the Development Potential Index (DPI) dataset as follows:

Human Modification of Indigenous Lands. The ecological integrity of Indigenous lands can be measured by the extent of their modification by specific human activities known to negatively impact ecosystems 67. We adopt this approach using the published global Human Modification (HM) map ${ }^{11}$. The HM is a geospatial map of the extent and estimated intensity of impacts from 13 anthropogenic stressors associated with human settlement (population density, built-up areas), agriculture (cropland, livestock), transportation (major roads, minor roads, two-tracks, and railroads), mining, energy production (oil wells and wind turbines), and electrical infrastructure (powerlines and night-time lights). We note that although the HM captures many human impacts, it does not include timber production or selective logging, pastureland, recreational use, and hunting. $\mathrm{HM}$ is a $0-1$ metric that reflects the proportion that each 1$\mathrm{km}^{2}$ land area is modified by human activities based on the median year of 2016 . Following ${ }^{11,67}$ and based on the distribution of $\mathrm{HM}$ values globally and in protected areas, we categorized the modification of each cell as very low $(0.00 \leq H M \leq 0.01)$, low $(0.01 \leq H M \leq 0.10)$, moderate $(0.10<H M \leq 0.40)$, high $(0.40<\mathrm{HM} \leq 0.70)$, and very high $(0.70<\mathrm{HM} \leq 1.00)$ (Fig. 1a). Low modified lands represent natural or semi-natural areas that are no more than $10 \%$ modified and have less than two overlapping human stressors; moderately modified lands are $>10$ to $40 \%$ modified and have less than three overlapping human stressors; and highly modified lands are human-dominated areas with over $40 \%$ modification with five or more overlapping stressors. Based on these categories, we created corresponding "naturalness scores" ranging from 1 to 5 , assigning 5 to the most intact, natural lands (i.e., very low HM) and 1 to the most modified lands (i.e., very high $\mathrm{HM}$ ).

Development Pressure on Indigenous Lands. We used published development potential indices (DPIs) ${ }^{12}$ for renewable energy, oil and gas, mining, and agricultural sectors and created an additional urban DPI based on global urban growth projections from 2020 to $2050{ }^{68}$. DPIs are global, spatially-explicit land suitability maps at $1-\mathrm{km}$ resolution that depict development pressure from the potential expansion of 
renewable energy (concentrated and photovoltaic solar power, wind power, and hydropower), oil and gas (conventional and unconventional), mining (coal, metallic and non-metallic mining), and agriculture (crop and biofuels expansion) sectors. Each DPI has standardized 0-1 values that indicate low to high suitability for future industrial development expansion based on a) sector-specific land constraints on development (e.g., suitable land cover, slope); b) land suitability for sector expansion based on resource availability (sector-specific yields); and c) siting feasibility of new development (e.g., ability to transport resources or materials, access to demand centers, and proximity of existing development).

For each DPI, we binned the range of values into six pressure categories based on standardized z-score ranges following ${ }^{12}$ to characterize the development pressure on Indigenous lands as very low $\left(\leq 10^{\text {th }}\right.$ percentile), low $\left(>10^{\text {th }}-25^{\text {th }}\right.$ percentile), medium-low $\left(>25^{\text {th }}-50^{\text {th }}\right.$ percentile), medium-high $\left(>50^{\text {th }}-75^{\text {th }}\right.$ percentile), high $\left(>75^{\text {th }}-90^{\text {th }}\right.$ percentile), and very high $\left(>90^{\text {th }}\right.$ percentile). We calculated $z$-scores by mean-standardizing values per country under the assumption that national-level domestic demand will drive national-level resource extraction. Because urban DPI was derived from urban expansion probabilities based on population growth projections that were more restrictive than the DPI values (e.g., excluded suitable areas like flat land, near roads and existing urban areas once demand was met), we binned the upper $50^{\text {th }}$ percentile and lower $50^{\text {th }}$ percentile of non-zero urban DPI values into high or very high pressure categories, respectively. Based on pressure categories, we then assigned pressure scores ranging from 1 (very low category) to 6 (very high category) to each DPI, and then created a cumulative development pressure map across all DPIs by retaining the max cell score across all individual DPIs (Fig. 1b). All lands without a pressure category were assigned a score of 0.

To evaluate sector-specific drivers on Indigenous lands, we identified regions of high development pressure based on selecting cells with high or very high categories within any of the DPI maps (orange and red areas depicted in Fig. 1b). We determined the sector driver based on which of the five sector categories (i.e., renewable energy, oil and gas, mining, agriculture, or urban) had the highest pressure score for that cell (Fig. 1c). To illustrate, if a given cell had only one sector (e.g., agriculture) classified as very high (pressure score of 6), that sector was the identified driver. If a given cell had multiple sectors with similar scores and no clear max score, we assigned it as a having multiple sector drivers. We highlight a sector as the majority driver in a country if it made up $>50 \%$ of the high development pressure estimate for Indigenous lands.

Development Threat on Indigenous Lands. We estimated development threat on Indigenous lands as a function of their human modification categories (using the 1 to 5 naturalness scores) multiplied by their cumulative development pressure categories (using the 1 to 6 pressure scores). This produced a $1-\mathrm{km}$ resolution threat map for all Indigenous lands with scores ranging from 0 to 30 , where 0 identifies Indigenous lands lacking any development pressure and 30 identifies Indigenous lands in the best ecological condition (i.e., least modified $=5$ ) and the highest potential for industrial expansion (i.e., very high development pressure $=6$ ). For visualization purposes, we binned the range of threat scores into six categories (very high, high, moderate, low, very low, none) using Jenks Natural Breaks (Fig. 1d). 
Authority-Capacity-Support Index. National-level indices have been developed to assess risk and guide prioritization for a variety of purposes, including natural hazards or climate-related events $13,14,62$, food system sustainability ${ }^{69}$, food insecurity (https://fews.net/), commodity supply chains ${ }^{70}$, and nature conservation ${ }^{71}$. To our knowledge, our Authority-Capacity-Support index is the first global composite index that captures the socio-economic and political contexts with relevance to continued stewardship of Indigenous lands by IP confronting industrial development pressures. We selected a suite of nationallevel indicators that can either encourage or hinder the development of localized enabling conditions. We focused on national-level indicators that characterize contexts that: (1) strengthen and secure IP' rights and decision-making authority (Authority sub-index); (2) promote the capacity for their engagement and representation in decision-making processes (Capacity_sub-index); and (3) provide capital and support for Indigenous-led conservation and sustainable development (Support sub-index) (Fig. 2).

We used published data from publicly available datasets that were global in extent and based on the most-up-to-date information (data sources from $2013(n=1), 2015(n=1), 2018(n=4))$. We prioritized indicators that were applicable to the concept in question and had theoretical and empirical support or broad utilization in other global prioritizations. Prior to selecting the final set of indicators, we tested for scale reliability among the full suite of indicators considered for each of the ACS sub-indices using Cronbach's alpha (a). This test provided a measure of internal consistency within the suite of indicators selected and a statistic that allows for evaluation of their suitability as complementary measures of the same sub-component. Based on calculations of Cronbach's alpha (a), internal reliability was considered "acceptable" for indicators of the Authority sub-index $(a=0.742)$ and "good" for indicators of the Capacity and Support sub-indices ( $\alpha=0.848$ and 0.889 , respectively) (Supplemental Figure 2 ). We considered three, four, and six national-level indicator datasets for the Authority, Capacity, and Support sub-indices, respectively, and ultimately retained two per index after consideration of their correlation statistics (See Supplemental Tables 2-4, Supplemental Figure 1).

Authority. For the Authority sub-index, we retained LandMark's index of IP' legal security ${ }^{72}$ and World Bank's Political Stability Index ${ }^{73}$. The LandMark index provides a measure of how well a nation's laws support IP' rights over their land and resources ${ }^{74}$ (see Supplemental material for further details on the components of various indices). Tenure security is noted to increase the motivation for collective action to sustainably manage territory and resources ${ }^{75,76}$. Thus, secure rights over territories and resources can enable better outcomes for IP confronting development pressure by empowering them with the legitimacy and authority to act as decision-makers, increasing their accountability for the decisions made, and improving their capacity for collective action in the sustainable management of local resources ${ }^{44,45}$. We view political stability as complimentary to LandMark's indicator of IP' legal security. The Political Stability Index is based on perceptions of political instability or politically motivated violence and considers instances of civil unrest, ethnic and international tension, armed conflict, violent demonstration, and internal/external conflict ${ }^{77}$. We expect political stability to have a positive and complementary effect on the strength and security of IP's rights and decision-making authority since more stable national governments tend to uphold their constituents' rights and help to enforce and mitigate potential conflicts. 
In contrast, unstable governments can result in periodic abuses ${ }^{78}$, loss of recognition and enforcement of IP' rights, and even (re)appropriation and dispossession of IP' homelands ${ }^{78}$.

Capacity. For the Capacity sub-index, we included World Bank's Control of Corruption Index ${ }^{73}$ and the World Resource Institute's Environmental Democracy Index ${ }^{79}$. The Control of Corruption Index reflects perceptions of the extent to which a government can address problems with public power exercised for private gain, as well as the potential for capture by elites and private interests. We expect control of corruption to be positively correlated with the capacity for IP' representation in the decision-making process, as higher values suggest a context favoring fairness and equity, where protections for the most marginalized and vulnerable exist to discourage power imbalances ${ }^{77}$. There is also evidence to suggest that control of corruption is important to environmental outcomes, given that countries with stronger control of corruption exhibit significantly lower environmental destruction over time ${ }^{80}$. The Environmental Democracy Index characterizes the extent to which a country's citizens enjoy access to information, participation, and justice in environmental matters. It consists of different legal indicators concerned with the development and implementation of relevant legislation (e.g., laws and regulations governing freedom-of-information, requirements for consultation and environmental impact assessment, regulations on extractive industries, etc.), as well as indicators that assess their efficacy in practice ${ }^{79}$. Higher values for environmental democracy suggest a context that promotes the capacity for both engagement and representation in decision-making processes.

Support. For the Support sub-index, we included the United Nation's Human Development Index (HDI) 81 and country-level investments in the UN's Sustainable Development Goals (SDGs) ${ }^{82}$. The HDI is a multidimensional index that describes human well-being with respect to life expectancy, education attainment, and standard of living. Higher HDI scores suggest the availability of adequate human, social, and financial capital within the population at-large to prioritize and make such local investments. They also suggest a context that allows for more latitude to be selective about the types of development accepted; whereas lower HDI scores suggest a vulnerability to accepting any form of potential development, and a diminished incentive to pursue competing priorities (e.g., biodiversity conservation vs. GDP). These relationships are supported by others that have found that countries with rapidly expanding economies and higher HDI scores exhibit subtle improvements in environmental condition ${ }^{80}$. Finally, we included country-level investments made in support of the United Nation's SDGs ${ }^{83}$, which totaled nearly $\$ 1.52$ trillion dollars between 2000 to 2013. Country recipients of higher SDG investments are assumed to have greater potential to support IP in achieving Indigenous-led conservation and sustainable development. Yet, with this indicator, we cannot determine the distribution of national-level investments or differentiate specific beneficiaries, though several of the 17 SDGs include Indigenous-specific indicators (Supplemental Table 5).

We constructed the ACS Index as a hierarchical, geometric mean of the three sub-indices (authority, capacity, and support) and their two indicators (as described above), according to the formula: 
$\mathrm{ACS}_{i}=$ Geomean (Authority Geomean (Ind1, Ind2); Capacity Geomean (Ind1, Ind2);

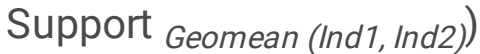

where Ind1 and Ind2 refers to the two indicators included in each of the sub-indices. Similar to other global metrics ${ }^{69}$, we used a geometric mean given the non-compensatory nature of indices and domains and to control for any unequal or skewed values across indicators, or residual correlations across domains. We also excluded within-domain indicators that were closely correlated (Supplementary Table 1), and equally weighted sub-indices due to lack of justification for differential weighting. Prior to calculating the sub-indices, we transformed individual indicators with skewed values, reflected their values to ensure consistent valence, and rescaled (normalized) their range of values from $0-1$, such that a value of 0 indicated the lowest authority, capacity or support score and a value of 1 indicated the highest (Fig. 2, Supplementary Figure 3). Lastly, an ACS score was only calculated for countries where all three sub-indices were present $(n=199)$. We assigned ranks to countries based on their ACS Index scores, such that a rank of 1 indicated a country with the most favorable context for IP to effectively govern and continue to steward their lands and resources. See Supplementary Methods for further details on preprocessing of indicator datasets, criteria for inclusion/exclusion of indicator datasets, and statistical results on indicator reliability and inter-correlations.

Development Risk to Indigenous Lands. We defined development risk to Indigenous lands to be a function of a country's development threat and its authority, capacity, and support score (Fig. 3). For each country, we calculated development risk to Indigenous lands by multiplying its mean development threat score by its inverse ACS Index score, such that higher values were consistent with highest risk, representing places of high development threat coupled with low authority, capacity, and support. The resulting risk scores obtained for each country were then rescaled so that values ranged from 0 (country with lowest development threat and highest ACS scores) to 1 (country with highest development threat and lowest ACS scores). For display purposes, all country maps were assigned to one of five categories of very high to very low based on continuous scores using Jenks Natural Breaks.

We then examined the influence of national contexts by evaluating 1) changes in country ranks for development threat vs. development risk (Fig. 4) and 2) how ranks and median scores varied across countries with respect to each of the Authority-Capacity-Support sub-indices (Table 1). A total of 88 countries had development threat scores and 79 countries had development risk scores.

\section{Declarations}

Data availability. The data used to map Indigenous lands are found in Supplementary Information in Garnett, Burgess ${ }^{1}$. The 1-km resolution maps of Human Modification, Development Potential Indices are publicly available on figshare ${ }^{84-86}$. Administrative boundaries for countries used in analyses are available from GADM (available at: https://gadm.org/). Methodology and data used to derive the ACS 
index are provided in the Supplementary Information and data used in our analyses are presented in Supplementary Data Table 1.

\section{Acknowledgements}

This work is dedicated to all the Indigenous land defenders who are fighting to protect their lands and waters from industrial development impacts. We thank Y. Masuda, M. Looker, L. Kehoe, M. Heiner, N. DeMello, R. Cortez, E.M. Madeira, C. Peters, and A. Burgess for helpful comments on this study and manuscript. We also thank C. Corrigan, H. Bingham, J. Van Montfort, and J. Stewart for elevating this topic in the policy arena. Funding for this research was provided in part by The Nature Conservancy (B.F, C.M.K), the Helsinki Institute of Sustainability Science (HELSUS) (A.F-L.), and USAID as part of the Bushmeat Research Initiative of the CGIAR research program on Forests, Trees and Agroforestry (J.E.F.).

\section{Author contributions}

C.M.K, B.F., and J.R.O. conceived and designed the study; C.M.K, B.F., and J.R.O. collected the data, conducted the analysis and interpreted the results; B.F., C.M.K, J.R.O., and S.B-M produced the figures and tables; C.M.K. and B.F. designed and wrote the manuscript. All authors contributed critically to revisions of the paper.

Competing financial interest: The authors declare no competing financial interests.

Supplementary Information for this paper includes:

Positionality and Framing Statement

Glossary of Key Terms

Supplementary Methods

Supplementary Figures 1 to 3

Supplementary Tables 1 to 6

Supplementary References

Supplementary Data 1

\section{References}

1. Garnett ST, et al. A spatial overview of the global importance of Indigenous lands for conservation. Nature Sustainability 1, 369-374 (2018).

2. Forest Peoples Programme IIFoB, Indigenous Women's Biodiversity Network, Centres of Distinction on Indigenous and Local Knowledge and Secretariat of the Convention on Biological Diversity,. Local 
Biodiversity Outlooks 2: The contributions of Indigenous Peoples and local communities to the implementation of the Strategic Plan for Biodiversity 2011-2020 and to renewing nature and cultures. In: Complement to the fifth edition of the Global Biodiversity Outlook (eds). Forest Peoples Programme (2020).

3. Walker WS, et al. The role of forest conversion, degradation, and disturbance in the carbon dynamics of Amazon indigenous territories and protected areas. Proc Natl Acad Sci 117, 3015-3025 (2020).

4. IPBES. Global assessment report on biodiversity and ecosystem services of the Intergovernmental Science-Policy Platform on Biodiversity and Ecosystem Services. (eds Brondizio ES, Settele J, Díaz S, Ngo HT). IPBES secretariat, Bonn, Germany (2019).

5. Gilberthorpe E, Hilson G. Natural resource extraction and indigenous livelihoods: Development challenges in an era of globalization. Routledge (2014).

6. Armstrong CG, Brown C. Frontiers are Frontlines: Ethnobiological Science Against Ongoing Colonialism. J Ethnobio/39, 14-31 (2019).

7. Begotti RA, Peres CA. Brazil's indigenous lands under threat. Science 363, 592 (2019).

8. Scheidel A, et al. Environmental conflicts and defenders: a global overview. Global Environ Change 63, 102104 (2020).

9. Fernández-Llamazares Á, et al. A State-of-the-Art Review of Indigenous Peoples and Environmental Pollution. Integr Environ Assess Manage 16, 324-341 (2020).

10. Farrell J, Burow PB, McConnell K, Bayham J, Whyte K, Koss G. Effects of land dispossession and forced migration on Indigenous peoples in North America. Science 374, eabe4943 (2021).

11. Kennedy CM, Oakleaf JR, Theobald DM, Baruch-Mordo S, Kiesecker J. Managing the middle: A shift in conservation priorities based on the global human modification gradient. Global Change Bio/ 25, 811-826 (2019).

12. Oakleaf JR, et al. Mapping global development potential for renewable energy, fossil fuels, mining and agriculture sectors. Scientific Data 6, 101 (2019).

13. Brinkmann N. Measuring Vulnerability to Natural Hazards: Towards Disaster Resilient Societies. United Nations University Press (2006).

14. Summers JK, Harwell LC, Smith LM, Buck KD. Measuring community resilience to natural hazards: the natural hazard resilience screening index (NaHRSI)-development and application to the United States. GeoHealth 2, 372-394 (2018). 
15. Garnett S, Joseph L, Watson J, Zander K. Investing in Threatened Species Conservation: Does Corruption Outweigh Purchasing Power? PLoS ONE 6, e22749-e22749 (2011).

16. Brooks JS, Waylen KA, Mulder MB. How national context, project design, and local community characteristics influence success in community-based conservation projects. Proc Natl Acad Sci 109, 21265-21270 (2012).

17. FAO. FAO Policy on Indigenous and Tribal Peoples. (eds). Food and Agriculture Organization of United Nations (2015).

18. TNC. Strong Voices, Active Choices: TNC's Practicioner Framework to Strengthen Outcomes for People and Nature. (eds). The Nature Conservancy (2017).

19. Mahajan SL, et al. A theory-based framework for understanding the establishment, persistence, and diffusion of community-based conservation. Conservation Science and Practice, e299 (2021).

20. Tseng T-WJ, et al. Influence of land tenure interventions on human well-being and environmental outcomes. Nature Sustainability 4, 242-251 (2021).

21. Robinson BE, et al. Incorporating land tenure security into conservation. Conservation Letters 11, e12383 (2018).

22. Brooks JS. Design features and project age contribute to joint success in social, ecological, and economic outcomes of community-based conservation projects. Conservation Letters 10, 23-32 (2017).

23. Kusters K, Buck L, de Graaf M, Minang P, van Oosten C, Zagt R. Participatory Planning, Monitoring and Evaluation of Multi-Stakeholder Platforms in Integrated Landscape Initiatives. Environ Manage 62, 170-181 (2018).

24. Wright JH, et al. Reframing the concept of alternative livelihoods. Conserv Bio/ 30, 7-13 (2016).

25. Franks P. Global Biodiversity Framework: equitable governance is key. (eds IIED) (2021).

26. Reyes-García V, et al. Recognizing Indigenous peoples' and local communities' rights and agency in the post-2020 Biodiversity Agenda. Ambio, (2021).

27. Kennedy CM, Oakleaf JR, Baruch-Mordo S, Theobald DM, Kiesecker J. Finding middle ground: Extending conservation beyond wilderness areas. Global Change Biol 26, 333-336 (2020).

28. Zárate-Toledo E, Patiño R, Fraga J. Justice, social exclusion and indigenous opposition: A case study of wind energy development on the Isthmus of Tehuantepec, Mexico. Energy Research \& Social Science 54, 1-11 (2019).

29. Ayompe LM, Schaafsma M, Egoh BN. Towards sustainable palm oil production: The positive and negative impacts on ecosystem services and human wellbeing. Journal of Cleaner Production 278, 
$123914(2021)$.

30. Rorato AC, Camara G, Escada MIS, Picoli MCA, Moreira T, Verstegen JA. Brazilian amazon indigenous peoples threatened by mining bill. Environ Res Lett 15, 1040a1043 (2020).

31. Shulist S. Transforming Indigeneity: Urbanization and language revitalization in the Brazilian Amazon. University of Toronto Press (2018).

32. Lyver PB, Timoti P, Davis T, Tylianakis J. Biocultural hysteresis inhibits adaptation to environmental change. Trends Ecol Evo/34, 771-780 (2019).

33. Abu-Saad I. Spatial Transformation and Indigenous Resistance: The Urbanization of the Palestinian Bedouin in Southern Israel. American Behavioral Scientist 51, 1713-1754 (2008).

34. Whyte KP. Justice forward: Tribes, climate adaptation and responsibility. Clim Change 120, 517530 (2013).

35. Cariño J. Indigenous peoples' right to free, prior, informed consent: reflections on concepts and practice. Ariz J Int'l \& Comp L 22, 19 (2005).

36. Artelle KA, et al. Supporting resurgent Indigenous-led governance: A nascent mechanism for just and effective conservation. Biol Conserv 240, 108284 (2019).

37. Chapin M, Lamb Z, Threlkeld B. Mapping Indigenous Lands. Annu Rev Anthrop 34, 619-638 (2005).

38. Aha B, Ayitey JZ. Biofuels and the hazards of land grabbing: Tenure (in)security and indigenous farmers' investment decisions in Ghana. Land Use Policy 60, 48-59 (2017).

39. Molebatsi C. Land grabbing in Botswana: Modern era dispossession. Town and Regional Planning 75, 44-53 (2019).

40. Pearce M, Louis R. Mapping indigenous depth of place. Amer Indian Cult Res J 32, 107-126 (2008).

41. Wainwright J, Bryan J. Cartography, territory, property: postcolonial reflections on indigenous counter-mapping in Nicaragua and Belize. cultural geographies 16, 153-178 (2009).

42. Paradza G, Mokwena L, Musakwa W. Could Mapping Initiatives Catalyze the Interpretation of Customary Land Rights in Ways that Secure Women's Land Rights? Land 9, 344 (2020).

43. Rye SA, Kurniawan NI. Claiming indigenous rights through participatory mapping and the making of citizenship. Political Geography 61, 148-159 (2017). 
44. Blackman A, Corral L, Lima ES, Asner GP. Titling indigenous communities protects forests in the Peruvian Amazon. Proc Natl Acad Sci 114, 4123-4128 (2017).

45. Baragwanath K, Bayi E. Collective property rights reduce deforestation in the Brazilian Amazon. Proc Natl Acad Sci 117, 20495-20502 (2020).

46. ICCA Consortium. Territories of Life. (eds). ICCA Consortium (2021).

47. Duncan T, Villarreal-Rosas J, Carwardine J, Garnett ST, Robinson CJ. Influence of environmental governance regimes on the capacity of indigenous peoples to participate in conservation management. PARKS-International Journal of Protected Areas and Conservation 24, 87-102 (2018).

48. Papillon M, Rodon T. Proponent-Indigenous agreements and the implementation of the right to free, prior, and informed consent in Canada. Environ Impact Assess Rev 62, 216-224 (2017).

49. Maclnnes A, Colchester M, Whitmore A. Free, prior and informed consent: how to rectify the devastating consequences of harmful mining for indigenous peoples'. Perspectives in Ecology and Conservation 15, 152-160 (2017).

50. Colchester M, Chao S. Respecting Free, Prior and Informed Consent: Practical Guidance for Governments, Companies, NGOs, Indigenous Peoples and Local Communities in Relation to Land Acquisition. In: Governance of tenure technical guide; no. 3 (eds). Food and Agriculture Organization of the United Nations (FAO) (2014).

51. Adade Williams P, Sikutshwa L, Shackleton S. Acknowledging Indigenous and Local Knowledge to Facilitate Collaboration in Landscape Approaches-Lessons from a Systematic Review. Land 9, 331 (2020).

52. Tengö $\mathrm{M}$, et al. Weaving knowledge systems in IPBES, CBD and beyond-lessons learned for sustainability. Current Opinion in Environmental Sustainability 26-27, 17-25 (2017).

53. Zimmerman MG, Reames TG. Where the wind blows: Exploring barriers and opportunities to renewable energy development on United States tribal lands. Energy Research \& Social Science 72, 101874 (2021).

54. Heiner $\mathrm{M}$, et al. Moving from reactive to proactive development planning to conserve Indigenous community and biodiversity values. Environ Impact Assess Rev 74, 1-13 (2019).

55. Salzman J, Bennett G, Carroll N, Goldstein A, Jenkins M. The global status and trends of Payments for Ecosystem Services. Nature Sustainability 1, 136-144 (2018).

56. Robinson CJ, James G, Whitehead PJ. Negotiating Indigenous benefits from payment for ecosystem service (PES) schemes. Global Environ Change 38, 21-29 (2016). 
57. World Bank. World Bank Environmental and Social Framework. (eds). World Bank (2016).

58. IFC. Performance Standard 7 Indigenous Peoples. (eds). International Finance Corporation (2012).

59. Tallis H, Kennedy CM, Ruckelshaus M, Goldstein J, Kiesecker JM. Mitigation for one \& all: An integrated framework for mitigation of development impacts on biodiversity and ecosystem services. Environ Impact Assess Rev 55, 21-34 (2015).

60. Sutherland L. \$1.7 billion pledged in support of Indigenous and local communities' land tenure. In: Mongabay (eds) (2021).

61. Johnson JA, Kennedy CM, Oakleaf JR, Baruch-Mordo S, Polasky S, Kiesecker J. Energy matters: Mitigating the impacts of future land expansion will require managing energy and extractive footprints. Ecol Econ 187, 107106 (2021).

62. Brooks N, Adger W, Kelly P. The determinants of vulnerability and adaptive capacity at the national level and the implications for adaptation. Global Environ Change 15, 151-163 (2005).

63. United Nations Development Program (UNDP). Human Development Report 2016: Human Development for Everyone. (eds). UNDP (2016).

64. Tomlinson K. Indigenous rights and extractive resource projects: negotiations over the policy and implementation of FPIC. The International Journal of Human Rights 23, 880-897 (2019).

65. Barelli M. Free, prior and informed consent in the aftermath of the UN Declaration on the Rights of Indigenous Peoples: developments and challenges ahead. The International Journal of Human Rights 16, 1-24 (2012).

66. Global Witness. Defending Tomorrow: The climate crisis and threats against land and environmental defenders. (eds). Global Witness (2020).

67. Riggio J, et al. Global human influence maps reveal clear opportunities in conserving Earth's remaining intact terrestrial ecosystems. Global Change Bio/ 26, 4344-4356 (2020).

68. Zhou Y, Varquez ACG, Kanda M. High-resolution global urban growth projection based on multiple applications of the SLEUTH urban growth model. Scientific Data 6, 34 (2019).

69. Bene C, et al. Global map and indicators of food system sustainability. Scientirfic Data 6, (2019).

70. Lèbre É, Owen JR, Corder GD, Kemp D, Stringer M, Valenta RK. Source Risks As Constraints to Future Metal Supply. Environ Sci Technol 53, 10571-10579 (2019).

71. Lindsey PA, et al. Relative efforts of countries to conserve world's megafauna. Global Ecology and Conservation 10, 243-252 (2017). 
72. Wily LA, et al. Indicators of the Legal Security of Indigenous and Community Lands. http://www.landmarkmap.org/data/ (Accessed May 2019) (2018).

73. Kaufmann D, Kraay A, Mastruzzi M. The Worldwide Governance Indicators Methodology and Analytical Issues. http://info.worldbank.org/governance/wgi/ (Accessed 27 March 2020) (2010).

74. Alden Wily L. Customary tenure: remaking property for the 21 st century. Comparative Property Law: Global Perspectives, 458-478 (2016).

75. Agrawal A, Ostrom E. Collective action, property rights, and decentralization in resource use in India and Nepal. Politics \& Society 29, 485-514 (2001).

76. Cox M, Arnold G, Tomás SV. A review of design principles for community-based natural resource management. Ecol Soc 15, 38 (2010).

77. Kaufmann D, Kraay A, Mastruzzi M. The worldwide governance indicators: methodology and analytical issues. Hague Journal on the Rule of Law 3, 220-246 (2011).

78. Ribot J, Agrawal A, Larson AM. Recentralizing while decentralizing: How national governments reappropriate forest resources. World Devel 34, 1864-1886 (2006).

79. Worker J, De Silva L. The Environmental Democracy Index Technical Note. www.environmentaldemocracyindex.org (Accessed September 2019) (2015).

80. Venter $\mathrm{O}$, et al. Sixteen years of change in the global terrestrial human footprint and implications for biodiversity conservation. Nat Commun 7, (2016).

81. United Nations Development Program (UNDP). Human Development Index. http://hdr.undp.org/en/content/human-development-index-hdi (Accessed 27 March 2020) (2019).

82. Sethi T, Custer S, Turner J, Sims J, DiLorenzo M, Latourell R. AIDData. https://www.aiddata.org/data/financing-to-the-sdgs-dataset (Accessed September 2019) (2017).

83. Sachs J, Schmidt-Traub G, Kroll C, Lafortune G, Fuller G. Sustainable Development Report 2019. (eds). Berelsmann Siftung and Sustainable Development Solutions Network (SDSN). (2019).

84. Kennedy CM, Oakleaf JR, Theobald DM, Baruch-Mordo S, Kiesecker J. Global Human Modification. https://doi.org/10.6084/m9.figshare.7283087 (2018).

85. Oakleaf JR, et al. Global development potential indices for renewable energy, fossil fuels, mining and agriculture sectors. https://doi.org/10.6084/m9.figshare.c.4249532 (2019).

86. Zhou Y, Varquez ACG, Kanda M. High-resolution global urban growth projection based on multiple applications of the SLEUTH urban growth model. https://doi.org/10.26188/5c2c5d0ed52d7 (2019). 


\section{Tables}

Tables 1-2 are in the supplementary files section.

\section{Figures}

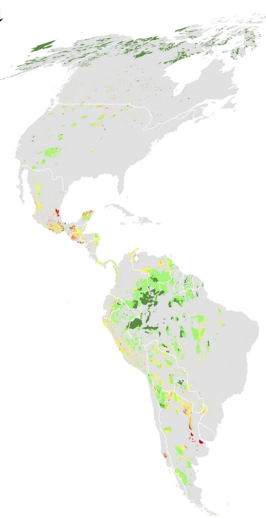

$\mathrm{c}$

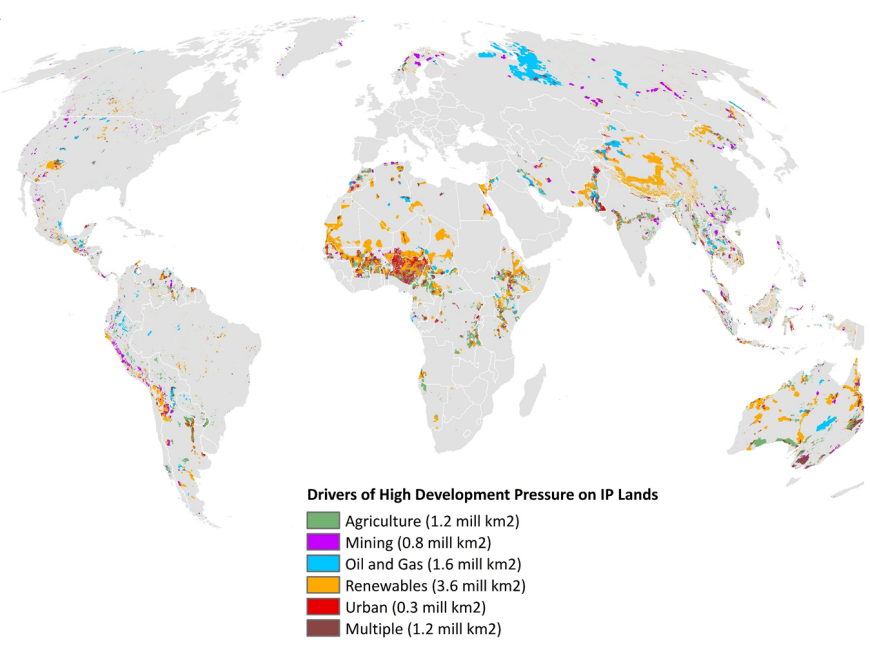

b
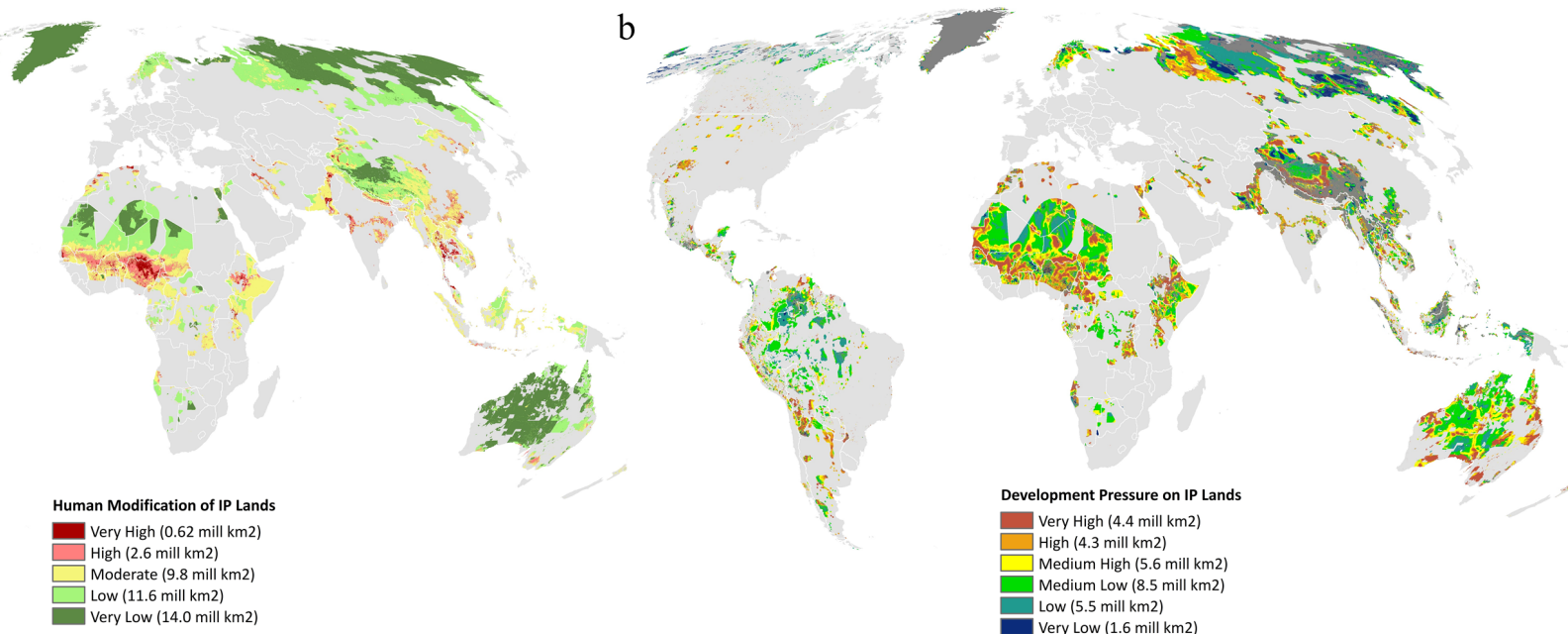

d

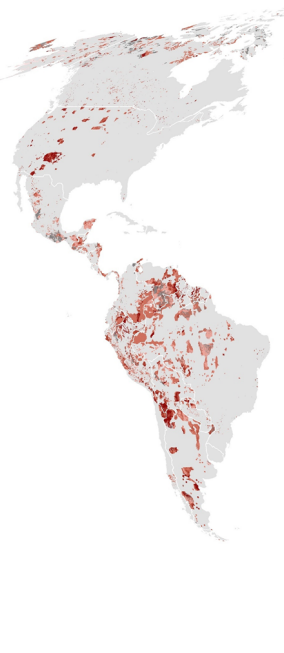

Pressure on IP Lands

Very High $(4.4$ mill $\mathrm{km} 2)$

High $(4.3 \mathrm{mill} \mathrm{km} 2)$

Medium High (5.6 mill $\mathrm{km} 2)$

Low (5.5 mill km2)

Very Low (1.6 mill km2)
None $(8.7$ mill km2)

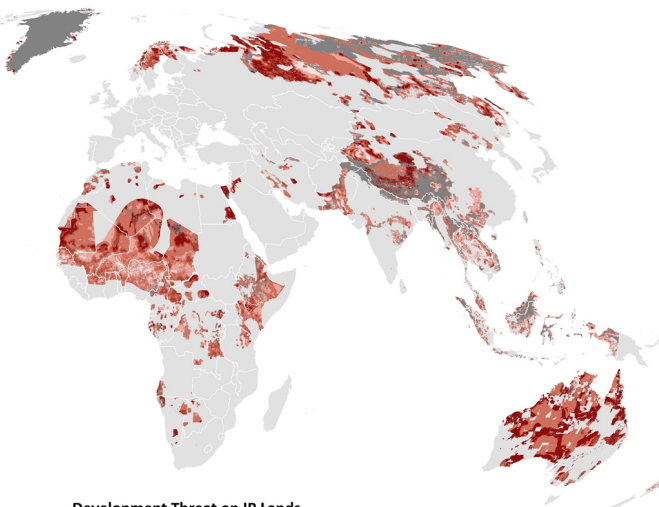

Development Threat on IP Lands

Very High (4.8 mill km2)

High (3.8 mill km2)

Low (5.1 mill km2)

ery Low (2.0 mill km2)

None $(8.7 \mathrm{mill} \mathrm{km} 2)$

Figure 1

Global maps of development threats on Indigenous lands. Intersection of lands managed and/or controlled by IP ${ }^{1}$ with a, current extent of human modification of terrestrial lands as a proxy for ecological condition ${ }^{11} \mathrm{~b}$, cumulative future development pressure by industrial sectors ${ }^{12}, \mathrm{c}$, drivers of high development pressure from expansion by commercial agriculture, mining, fossil fuels, renewables, urbanization, or multiple sectors, and d, overall development threat based on current human modification multiplied by future development pressure. See methods for definitions of categories. 

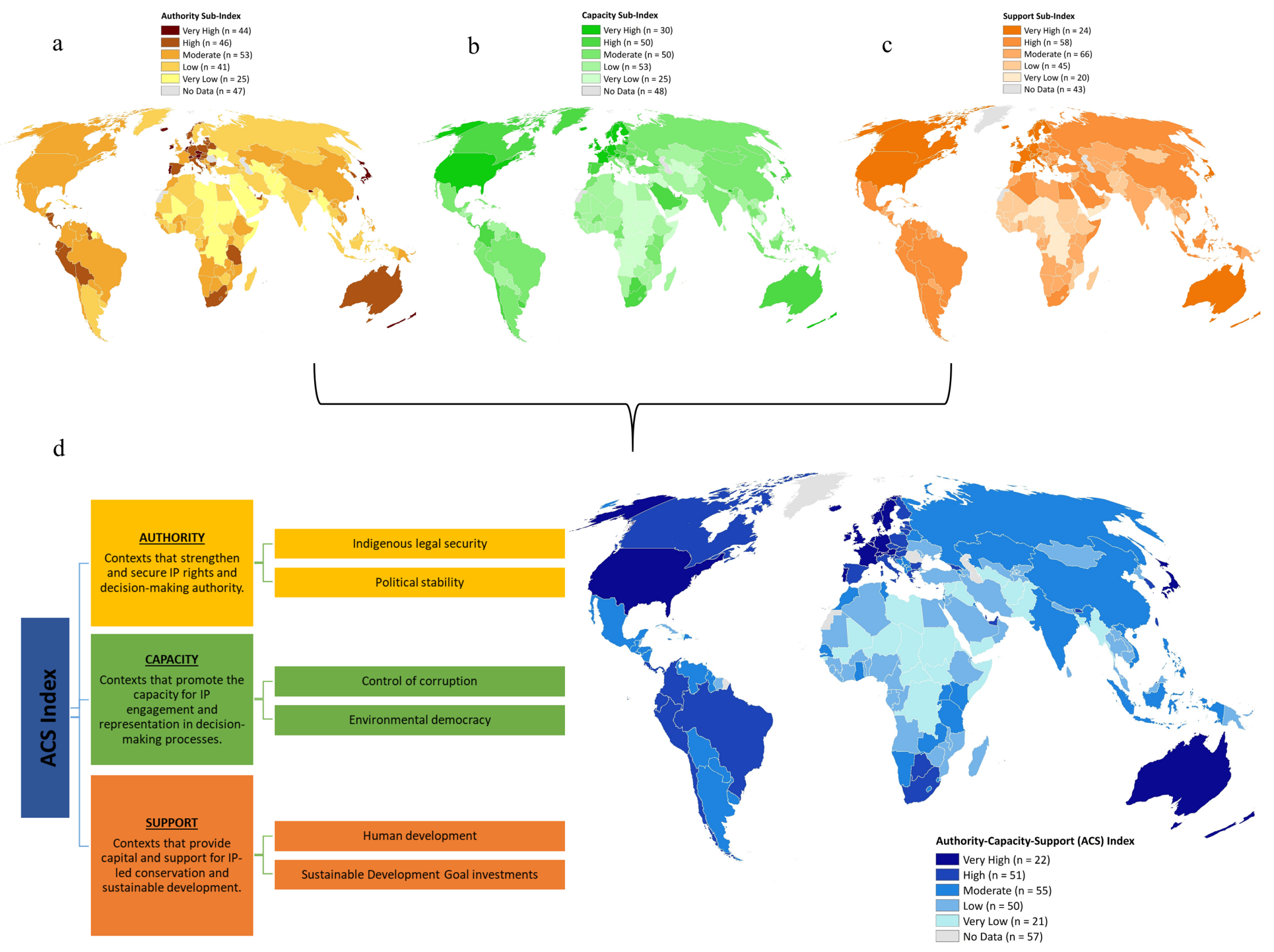

Figure 2

Global maps of the Authority-Capacity-Support Index representing national contexts influencing Indigenous Peoples' (IP) stewardship. National-level indicators for the contexts that a, strengthen and secure IP' rights and decision-making authority (Authority sub-index); b, promote the capacity for their engagement and representation in decision-making processes (Capacity sub-index); and c, provide capital and support for Indigenous-led conservation and sustainable development (Support sub-index). $d$, these national-level sub-indices were combined to create the composite Authority-Capacity-Support Index. 
$\mathrm{a}$

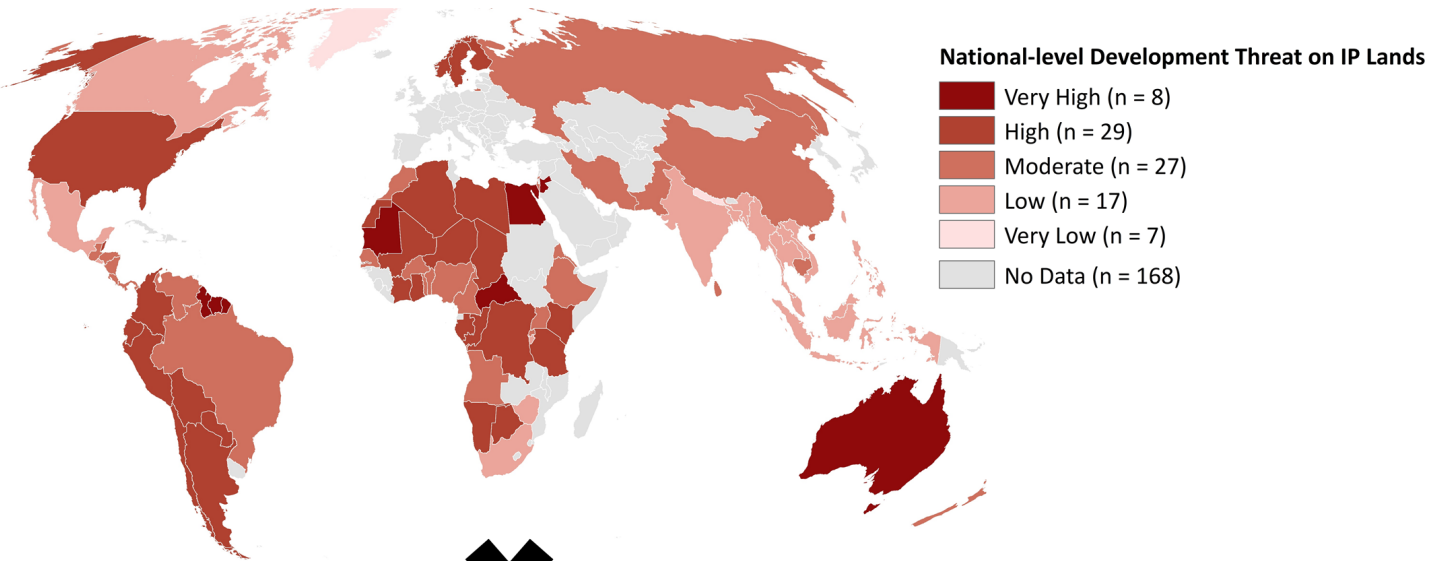

b

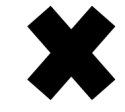

Authority-Capacity-Support (ACS) Index

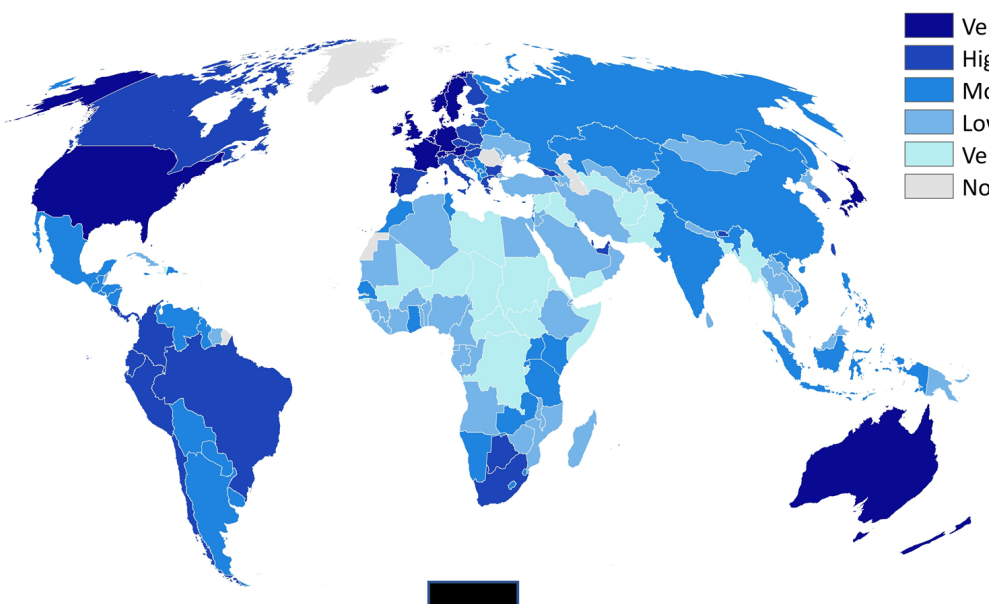

c

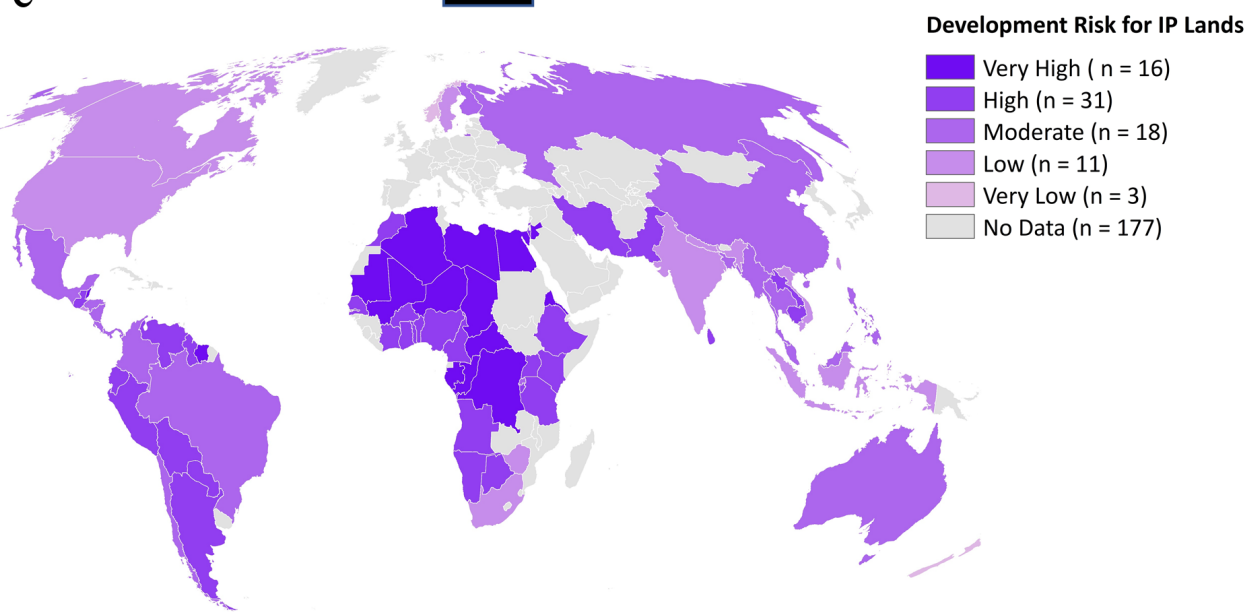

Figure 3

Global development risk to Indigenous lands. a, National-level mean development threat on Indigenous lands, b, national-level Authority-Capacity-Support Index, and c) national-level development risk derived from multiplication of map a and inverse of map $b\left(a \times b^{-1}=c\right)$. In each map, countries were assigned to one of six categories of very high to very low based on natural groupings using Jenks Natural Breaks Classification. 


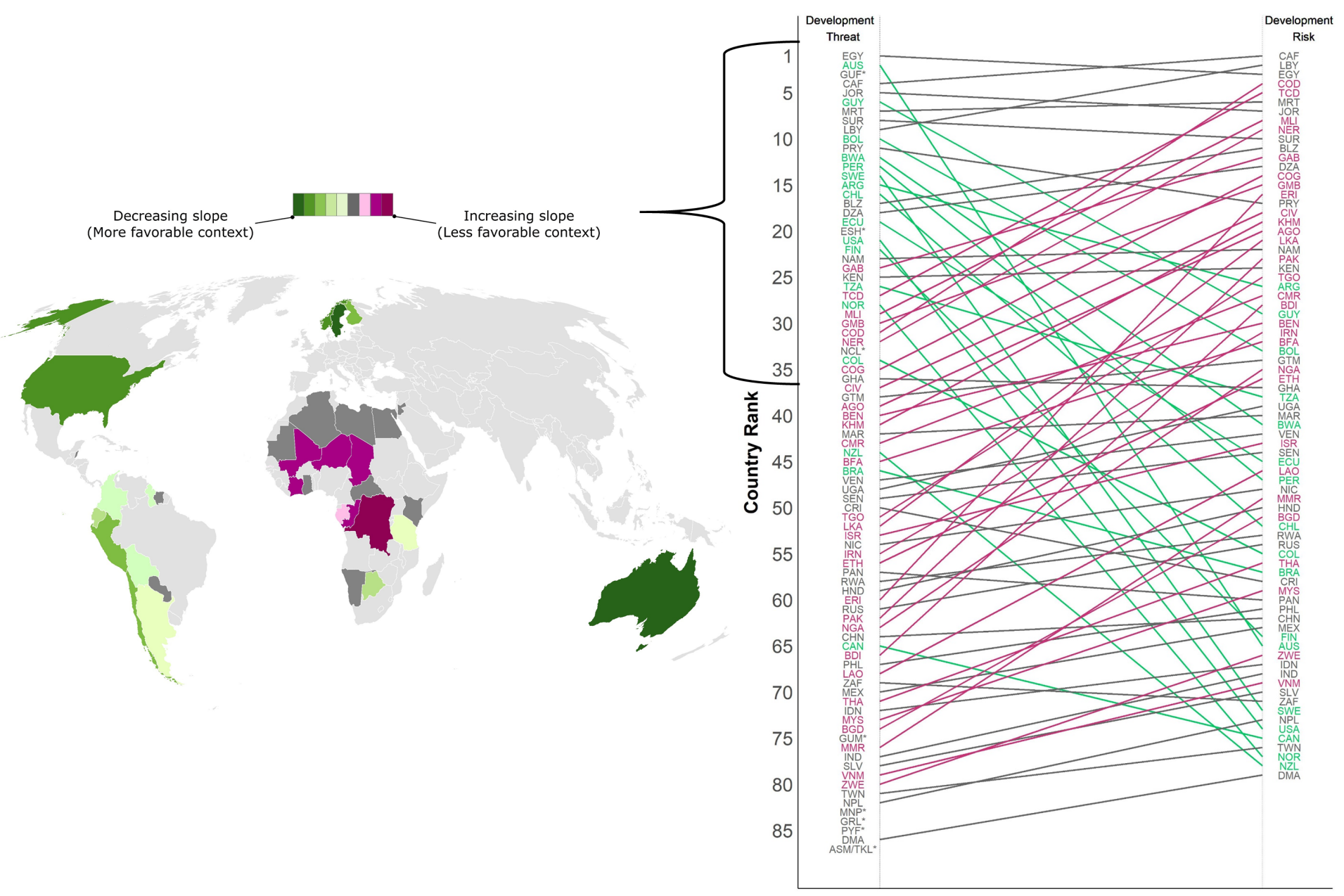

\section{Figure 4}

Effect of national-level context on development risk. a, Map of countries with high and very high development threat and $b$, slope graph for all countries showing rank changes in development threat relative to development risk considering national context represented by the ACS Index. On slope graph, countries are ranked by development threat on the left axis and development risk on the right axis, with rank \#1 having greatest threat and greatest risk respectively. Countries with notable rank changes are highlighted in the map and slope graph: 29 countries have positive rank changes $\geq 10$ (pink) suggestive of less favorable national contexts and 17 countries have negative rank changes $\leq 10$ (green) suggestive of more favorable national contexts. Dark grey denotes the 33 countries with negligible rank changes (< 10). Countries indicated by asterisk $\left(^{*}\right)$ on the slope graph lacked data to calculate a development risk score.

\section{Supplementary Files}

This is a list of supplementary files associated with this preprint. Click to download. 
- SupplementaryInformationforlndigenousLandsatRisk.pdf

- SupplementaryData1forlndigenousLandsatRisk.xlsx

- Tables.docx 